\title{
THERMAL EXPANSION OF TANTALUM
}

\author{
By Peter Hidnert
}

\section{ABSTRACT}

This paper gives data on the linear thermal expansion of three samples of worked and annealed tantalum over various temperature ranges between $-190^{\circ}$ and $+500^{\circ}$ C. A summary of available data by previous observers on the thermal expansion of tantalum is included.

Worked tantalum was found to expand practically the same as annealed tantalum. The following equation is given as the most probable second-degree equation for the expansion of tantalum between $20^{\circ}$ and $500^{\circ} \mathrm{C}$.:

$$
L_{t}=L_{o}\left[1+\left(6.59 t+0.00008 t^{2}\right) 10^{-6}\right]
$$

The coefficient of expansion of tantalum increases slightly with temperature. From $20^{\circ}$ to $100^{\circ} \mathrm{C}$. the average coefficient of expansion is $6.6 \times 10^{-6}$ per degree centigrade. Table 6 gives additional coefficients of expansion for various temperature ranges.

\section{CONTENTS}

I. Introduction

II. Materials investigated and uses of tantalum

III. Apparatus._. 890

IV. Results._.- 890

V. Summary

\section{INTRODUCTION}

Tantalum was discovered by Ekeberg, of Sweden, in 1802. He assigned the name tantalum, because "when placed in the midst of acids it is incapable of taking any of them up and saturating itself with them."

The earliest available value for the linear thermal expansion of tantalum between $0^{\circ}$ and $50^{\circ} \mathrm{C}$. was obtained by the Normal-Aichungskommission, of Germany. Later Disch and Worthing published some data on the linear thermal expansion of tantalum. Disch determined the expansion of a sample of tantalum over severaI temperature ranges between $-78^{\circ}$ and $+400^{\circ} \mathrm{C}$. and Worthing reported results of one set of observations from $300^{\circ}$ to $2,700^{\circ} \mathrm{K}$. A summary of these results is given in Table 1.

The present paper gives results of 15 sets of observations. One sample of worked tantalum and two samples of annealed tantalum were used in this investigation. Expansion determinations were made over various temperature ranges between $-190^{\circ}$ and $+500^{\circ} \mathrm{C}$. 
The author wishes to express his appreciation for the cooperation by the Fansteel Products Co., North Chicago, Ill. This company furnished the samples of tantalum and information about the preparation. Acknowledgment is due to H. W. Bearce and W. Souder, of the Bureau of Standards, for valuable suggestions and to H. S. Krider, of the Bureau of Standards, for assistance in the investigation.

TABLE 1.-Summary of expansion data on tantalum by previous observers

\begin{tabular}{|c|c|c|c|c|c|}
\hline Observer & Date & Material & $\begin{array}{l}\text { Tempera- } \\
\text { ture or } \\
\text { tempera- } \\
\text { ture range }\end{array}$ & $\begin{array}{l}\text { Coeffi- } \\
\text { cient of } \\
\text { linear } \\
\text { expan- } \\
\text { sion per } \\
\text { degree } \\
\text { centi- } \\
\text { grade }\end{array}$ & Expansion equation \\
\hline $\begin{array}{l}\text { Normal-Aichungs- } \\
\text { kommission } 1\end{array}$ & (?) & Tantalum.... & $\begin{array}{l}{ }^{\circ} \mathrm{C} \text {. } \\
0 \text { to } 50\end{array}$ & $\begin{array}{r}\times 10^{-8} \\
7.9\end{array}$ & \\
\hline Disch 2 ....... & 1921 & .....do. ${ }^{3}$ & $\left\{\begin{array}{l}-78 \text { to } 0 \\
0 \text { to } 100 \\
0 \text { to } 200 \\
0 \text { to } 300 \\
0 \text { to } 400\end{array}\right.$ & $\begin{array}{l}45.9 \\
46.6 \\
46.6 \\
46.7 \\
46.8\end{array}$ & $\left\{\begin{array}{l}L_{t}=L_{\bullet}\left[1+\left(6.46 t+0.00090 t^{2}\right) 10^{-6}\right], \\
\text { where } L_{t} \text { is the length at any } \\
\text { temperature } t \text { between } 0^{\circ} \text { and } \\
400^{\circ} \mathrm{C} \text {. and } L_{\circ} \text { the length at } 0^{\circ} \mathrm{C} \text {. }\end{array}\right.$ \\
\hline Worthing 8 & 1926 & Tantalum wire.. & $\left\{\begin{array}{r}27 \\
27 \text { to } 1,400 \\
27 \text { to } 2,400\end{array}\right.$ & $\begin{array}{l}{ }^{6} 6.6 \\
{ }^{6} 7.3 \\
{ }^{6} 7.8\end{array}$ & $\left\{\begin{array}{l}\frac{\Delta L}{L}=6.60 \times 10^{-6} \quad(T-300)+5.2 \times 10^{-10} \\
(T-300)^{2}, \text { where } L \text { is the length at } \\
300^{\circ} \mathrm{K} \text {. and } T \text { is any temperature } \\
\text { between } 300^{\circ} \text { and } 2,700^{\circ} \mathrm{K} \text {. }\end{array}\right.$ \\
\hline
\end{tabular}

1 Reported by von Bolton, Zeitschrift für Elektrochemie, 11, p. 45; 1905 . Other publications (von Bolton and Feuerlein, Electrotechnische Zeitschrift, 26, p. 105; 1905; and Escard, Revue Géneralé des Sciences, $24, \mathrm{p} .47$; 1913) state that the coefficient of expansion $7.9 \times 10^{-0}$ applies for the temperature range $0^{\circ}$ to $60^{\circ} \mathrm{C}$. or $0^{\circ}$ to $100^{\circ} \mathrm{C}$.

${ }_{2}$ Disch, Zeitschrift für Physik, 5, p. 173; 1921. Disch states that his equation satisfies the observations to an accuracy of $\pm 0.01 \mathrm{~mm} / \mathrm{m}$.

3 From Glühlampenwerk der Siemens und Halske A.-G., in Charlottenburg, Germany.

1 Computed from data given by observer.

s Worthing, Phys. Rev., 28, p. 190; 1926.

6 Computed from expansion equation.

\section{MATERIALS INVESTIGATED AND USES OF TANTALUM}

Three samples of tantalum were investigated. The following information relating to these samples was furnished by the company that supplied the material:

Sample 1235 is practically chemically pure tantalum and has been worked to a considerable extent since its last anneal or heat treatment in a vacuum.

Samples 1236 and 1237 represent the metal in practically a state of complete anneal. The last heat treatment consisted in heating the material very close to its melting point in a vacuum furnace and maintaining the vacuum for some time in order to degas the metal as completely as possible. Very careful test of this metal would probably show that it still contains small amounts of hydrogen. Chemically, this is about as pure as it is possible to make the metal commercially. The only impurities which are probably present will be traces of iron, manganese, and possibly carbon, although the amount of any of these will be very small. This material after the final heat treatment was rolled lengthwise only enough to smooth up the metal and obtain as nearly uniform thickness as possible. Samples 1236 and 1237 will probably be considerably softer ${ }^{1}$ than sample 1235.

$1 \mathrm{~W}$. T. Sweeney, of this bureau, determined the hardness of two of these samples by means of the Vickers pyramid hardness testing machine made by Vickers (Ltd.), of London, England. A load of $30 \mathrm{~kg}$ was used. The hardness numbers for samples 1237 and 1235 were found to be 146 and 202, respectively. 
Table 2 gives the chemical composition and the density of the samples.

TABLE 2.-Chemical composition and density of tantalum

\begin{tabular}{|c|c|c|c|c|c|c|c|c|c|}
\hline \multirow{2}{*}{ Sample } & \multirow{2}{*}{ Treatment } & \multicolumn{7}{|c|}{ Chemical analyses 1} & \multirow{2}{*}{$\begin{array}{l}\text { Density }{ }^{2} \\
\text { in } \mathrm{g} / \mathrm{cm}^{3} \\
\text { at } 23^{\circ} \mathrm{C} \text {. }\end{array}$} \\
\hline & & $\begin{array}{l}\text { Tanta- } \\
\text { lum }^{3}\end{array}$ & $\begin{array}{l}\text { Man- } \\
\text { ganese }\end{array}$ & Iron & $\begin{array}{l}\text { Car- } \\
\text { bon }\end{array}$ & $\begin{array}{l}\text { Molyb- } \\
\text { denum }\end{array}$ & Silicon & $\begin{array}{l}\text { Colum } \\
\text { bium }\end{array}$ & \\
\hline & Worked... & $\begin{array}{l}\text { Per } \\
\text { cent } \\
99.9+\end{array}$ & $\begin{array}{l}\text { Per } \\
\text { cent } \\
0.019\end{array}$ & $\begin{array}{l}\text { Per } \\
\text { cent } \\
0.01\end{array}$ & $\begin{array}{c}\text { Per } \\
\text { cent } \\
<0.005\end{array}$ & $\begin{array}{c}\text { Per } \\
\text { cent } \\
<0.001\end{array}$ & $\begin{array}{c}\text { Per } \\
\text { cent } \\
\left({ }^{4}\right)\end{array}$ & $\begin{array}{l}\text { Per } \\
\text { cent } \\
()^{(5)}\end{array}$ & 16.57 \\
\hline $1236-$ & Annealed.. & $99.9+$ & .014 & .004 & $<.005$ & $<.001$ & $(4)$ & $(s)$ & $\begin{array}{l}16.53 \\
16.56\end{array}$ \\
\hline
\end{tabular}

1 Determined by R. M. Fowler, of this bureau.

2 Determined by E. L. Peffer, of this bureau (after the expansion tests).

3 Ignition of the metal to the oxide, $\mathrm{Ta}_{2} \mathrm{O}_{5}$, indicated a tantalum content greater than 99.9 per cent.

4 Not detected.

Not detected-if present, less than 0.10 per cent.

6 Cut from same bar as sample 1236.

The following résumé by Fansteel Products Co. ${ }^{2}$ includes uses to which tantalum has been put and uses which its properties suggest:

In considering the applications to which this metal is adapted the main points to be considered are its high melting point, its resistance to chemical corrosion, its tendency to absorb gases when heated, and the fact that it oxidizes when heated in air to a red heat. Among the uses for tantalum may be mentioned the following:

Dental instruments and dental spatulas.

Surgical tools.

Pen points.

Filament wire for incandescent lamps or thermionic tubes.

Plates and support wires for thermionic tubes.

Hypodermic needles.

Cathodes for use in electrochemical analysis.

Analytical weights, laboratory dishes, spatulas, stirrers, and other devices in which a perfectly acid-proof metal would be more suitable than porcelain or glass.

Parts of scientific instruments.

Acid-proof pumps and parts of commercial chemical equipment.

Electrolytic valves for the manufacture of rectifiers for obtaining direct current from alternating current course, as in battery chargers, electrolysis apparatus and radio.

For additional information about the preparation of tantalum, its physical and chemical properties, and its uses, the reader should refer to the papers mentioned in the footnote ${ }^{3}$ below and to the note at the end of this paper.

\footnotetext{
2 Eng. and Min. J., 116, p. 816; 1923.

${ }^{3}$ W. von Bolton, Das Tantal, Seine Darstellung und Seine Eigenschaften, Zeitschrift für Elektrochemie, 11, p. 45; 1905. W. von Bolton and Feuerlein, Die Tantallampe, eine neue Glühlampe der Firma Siemens und Halske A.-G., Elektrotechnische Zeitschrift, 26, p. 105; 1905. Smith, Observations on Columbium and Tantalum, The Chem. News, 92, p. 209; 1905. Siemens, Tantalum and Its Industrial Applications, The Chem. News, 100, p. 223; 1909; or The Chem. Engineer, 10, p. 207; 1909; or Engineering, 87, p. $601 ; 1909$. Escard, Le Tantals et Ses Applications Industrielles, Revue Générale des Sciences, 24, p. 47; 1913. Balke, The Story of the Production and Uses of Ductile Tantalum, Chem. and Met. Eng., 27, p. 1271; 1922; or Annual Report of the Smithsonian Institution, p. 233; 1923.
} 


\section{APPARATUS}

Two types of thermal expansion equipment were used in this research, namely, $(a)$ precision comparator and $(b)$ fused-quartz tube. The first type was described in $1926^{4}$ and the second in $1928 .^{5}$ All sets of observations except several at low temperatures were made by means of the precision comparator.

\section{RESULTS}

The linear thermal expansion of three samples of tantalum were investigated over various temperature ranges between $-190^{\circ}$ and $+500^{\circ} \mathrm{C}$. During the investigation it was found that tantalum

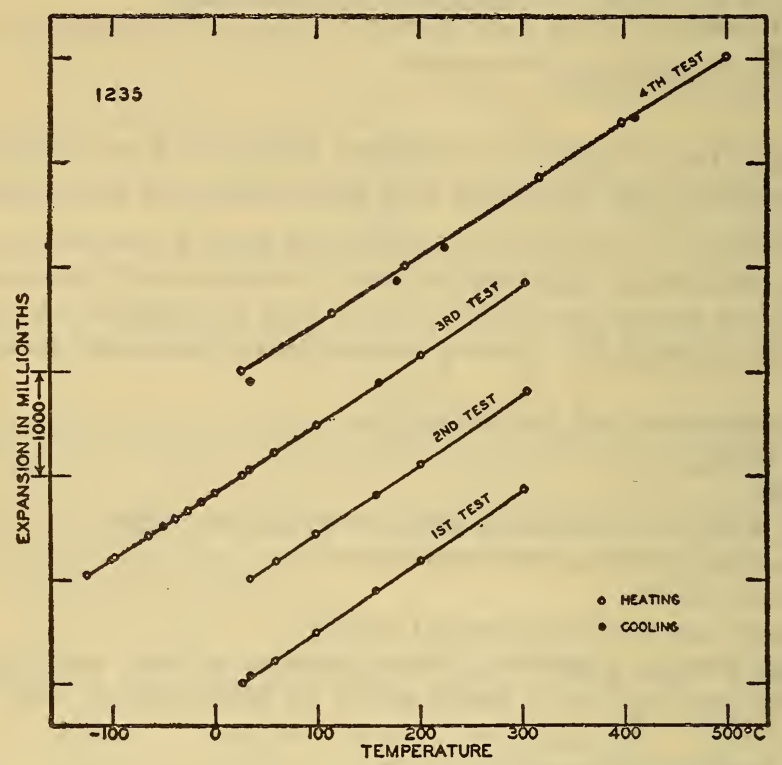

Figure 1.-Linear thermal expansion of worked tantalum from $-125^{\circ}$ to $+500^{\circ} \mathrm{C}$.

(See fig. 2 for additional tests)

oxidized in air at approximately $600^{\circ} \mathrm{C}$. The maximum temperature of the expansion tests, therefore, was maintained below this temperature.

The results obtained on worked and annealed tantalum are shown in Figures 1 to 4 , inclusive. The curves in these figures are plotted from different origins to display the individual characteristics of each curve. If drawn from the same origin, the curves would be so close together as to be confusing. The coefficients of expansion ${ }^{6}$ which were obtained from the expansion curves are given in Tables 3 and 4.

4 Souder and Hidnert, B. S. Sci. Papers, 21 (No. 524), p. 1; 1926.

B Hidnert and Sweeney, B. S. Jour. Research, 1 (No. 29), p. 771; 1928.

${ }^{6}$ All coefficients of expansion given in this paper were derived from the observations on heating. 


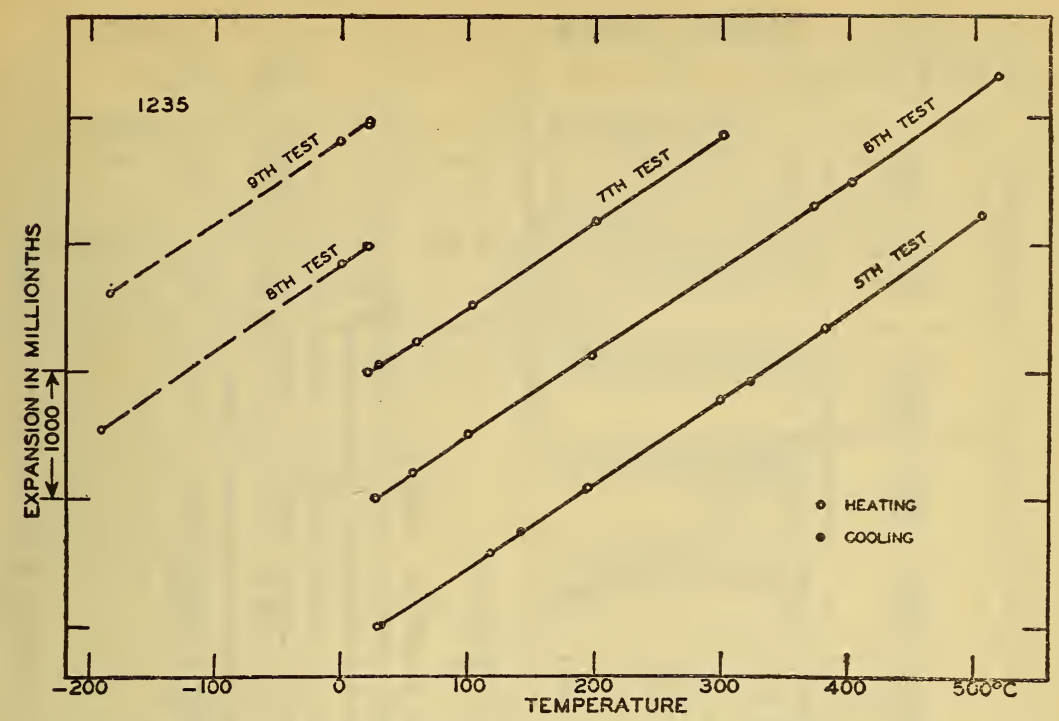

FIGURE 2.-Linear thermal expansion of worked tantalum from $-190^{\circ}$ to $+500^{\circ} \mathrm{C}$.

(See fig. 1 for previous tests)

The last column in Table 3 shows the differences in length before and after the expansion tests. The plus $(+)$ sign indicates an increase in length and the minus $(-)$ sign a decrease in length.

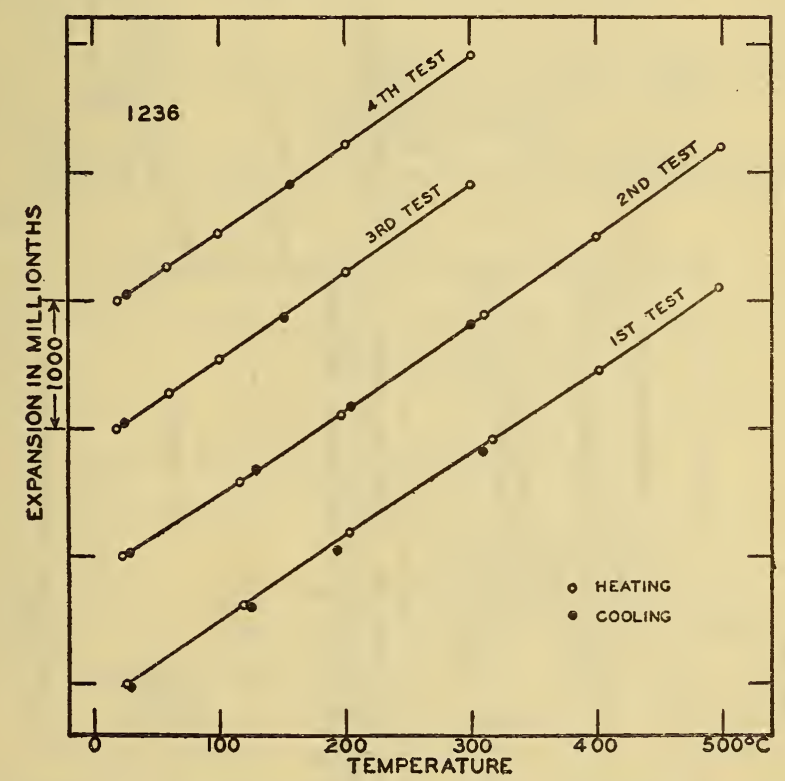

FiguRe 3.-Linear thermal expansion of annealed tantaum from $20^{\circ}$ to $500^{\circ} \mathrm{C}$. 

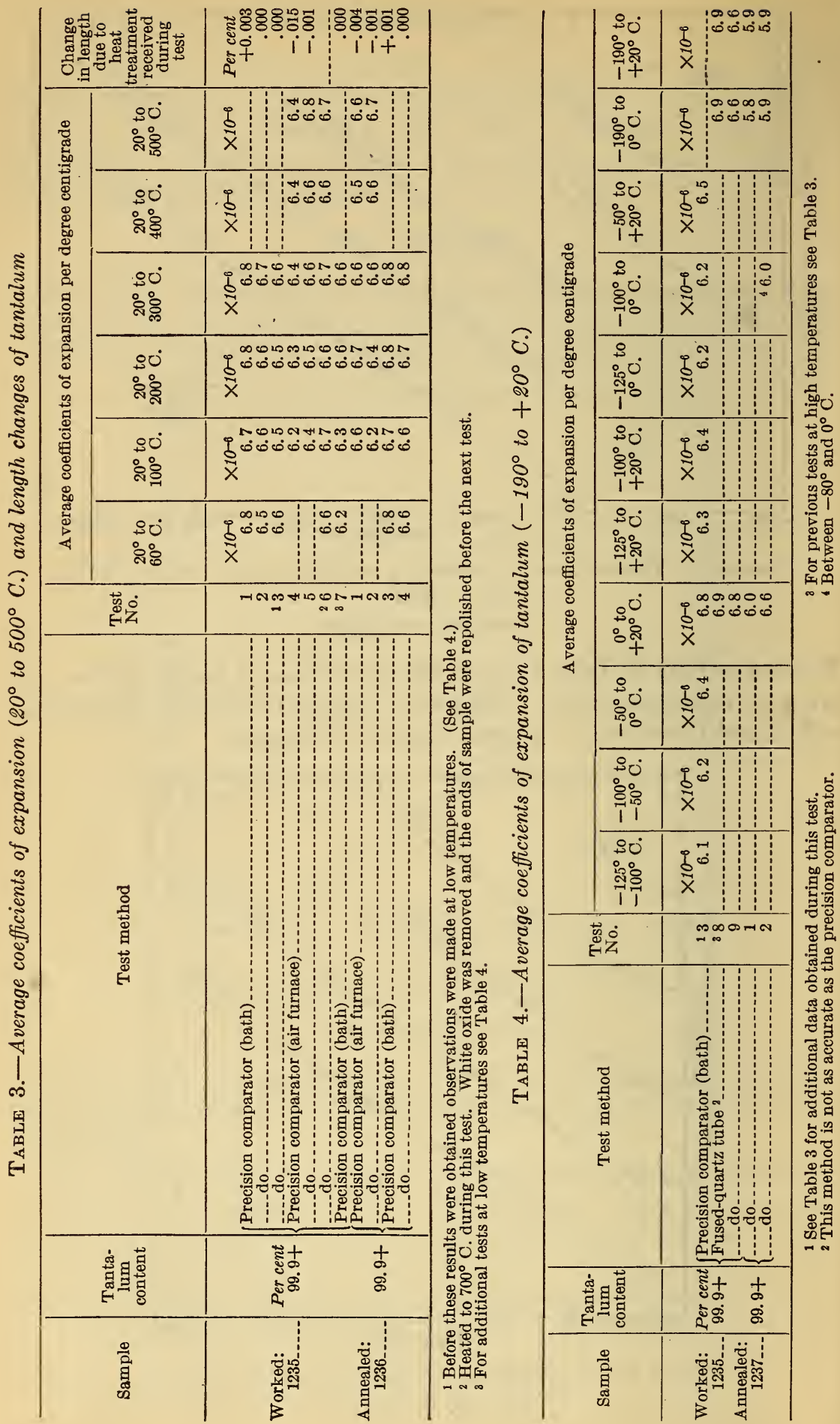
Table 5 gives expansion equations for samples 1235 and 1236 . These equations were derived, by the method of least squares, from the observations on heating. For sample 1235 the observations from tests 1 to 7 , inclusive, were used, and for sample 1236 the observations from tests 1 to 4 , inclusive, were employed in the derivation of the equations. $L$ represents the length of the metal at $20^{\circ} \mathrm{C}$. and $\triangle L$ represents the expansion or change in length from $20^{\circ} \mathrm{C}$. to any temperature $t$ between $20^{\circ}$ and $500^{\circ} \mathrm{C}$.

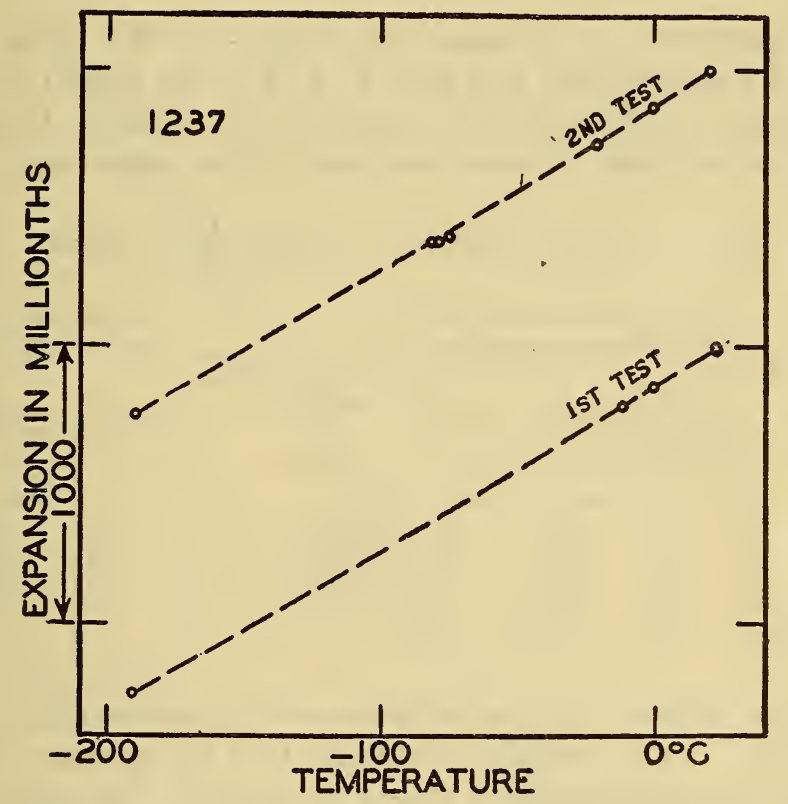

FIgURE 4.-Linear thermal expansion of annealed tantalum from $-190^{\circ}$ to $+20^{\circ} \mathrm{C}$.

TABLE 5.-Expansion equations of tantalum

\begin{tabular}{|c|c|c|}
\hline Sample & Expansion equation & $\begin{array}{l}\text { Probable } \\
\text { error of } \Delta L\end{array}$ \\
\hline $\begin{array}{c}\text { Worked: } \\
1235 \\
\text { Annealed: } \\
1236 .\end{array}$ & $\begin{array}{l}\Delta L=L\left[6.53(t-20)+0.00023(t-20)^{2}\right] 10^{-6} \\
\Delta L=L\left[6.66(t-20)-0.00007(t-20)^{2}\right] 10^{-6}\end{array}$ & $\begin{array}{l} \pm 0.000023 L \\
\pm .000016 L\end{array}$ \\
\hline
\end{tabular}

The expansion curves represented by the equations in Table 5 are nearly linear. The maximum deviation between these curves for worked and annealed tantalum is 14 millionths of the original length and occurs at $237^{\circ} \mathrm{C}$. Since this deviation is approximately equal to the probable error of each equation, it is concluded that the samples of worked and annealed tantalum expand the same. 
The equations of Table 5 may be transformed into the following: Worked tantalum:

$$
L_{t}=L_{o}\left[1+\left(6.52 t+0.00023 t^{2}\right) 10^{-6}\right]
$$

Annealed tantalum:

$$
L_{t}=L_{o}\left[1+\left(6.66 t-0.00007 t^{2}\right) 10^{-6}\right]
$$

Average of equations (1) and (2):

$$
L_{t}=L_{o}\left[1+\left(6.59: t+0.00008 t^{2}\right) 10^{-6}\right]
$$

In these equations $L_{t}$ represents the length of the metal at any temperature $t$ between $20^{\circ}$ and $500^{\circ} \mathrm{C}$. and $L_{o}$ the length at $0^{\circ} \mathrm{C}$.

The average coefficients of expansion for various temperature ranges given in Table 6 were computed from equations (1), (2),

\begin{tabular}{|c|c|c|c|c|c|c|c|}
\hline \multirow{2}{*}{$\begin{array}{l}\text { Temperature range } \\
\text { in degrees centi- } \\
\text { grade }\end{array}$} & \multicolumn{3}{|c|}{$\begin{array}{l}\text { A verage coefficients of expan- } \\
\text { sion per degree centigrade }\end{array}$} & \multirow{2}{*}{$\begin{array}{l}\text { Temperature range } \\
\text { in degrees centi- } \\
\text { grade }\end{array}$} & \multicolumn{3}{|c|}{$\begin{array}{l}\text { Average coefficients of expan- } \\
\text { sion per degree centigrade }\end{array}$} \\
\hline & $\begin{array}{l}\text { Worked } \\
\text { tantalum }\end{array}$ & $\begin{array}{c}\text { Annealed } \\
\text { tantalum }\end{array}$ & A verage & & $\begin{array}{c}\text { Worked } \\
\text { tantalum }\end{array}$ & $\begin{array}{l}\text { Annealed } \\
\text { tantalum }\end{array}$ & A verage \\
\hline $\begin{array}{l}20 \text { to } 60 \\
60 \text { to } 100 \\
200 \text { to } 2000 \text { to } 400 \\
400 \text { to } 500\end{array}$ & $\begin{array}{r}\times 10^{-6} \\
6.5 \\
6.6 \\
6.6 \\
6.6 \\
6.7 \\
6.7\end{array}$ & $\begin{array}{r}\times 10^{-6} \\
6.7 \\
6.6 \\
6.6 \\
6.6 \\
6.6 \\
6.6\end{array}$ & $\begin{array}{r}\times 10^{-6} \\
6.6 \\
6.6 \\
6.6 \\
6.6 \\
6.6 \\
6.7\end{array}$ & $\begin{array}{l}20 \text { to } 100 \\
20 \text { to } 20000 \text { to } 300 \\
20 \text { to } 4000 \text { to } 500 \\
20\end{array}$ & $\begin{array}{r}\times 10^{-6} \\
6.5 \\
6.6 \\
6.6 \\
6.6 \\
6.6\end{array}$ & $\begin{array}{r}\times 10^{-6} \\
6.7 \\
6.6 \\
6.6 \\
6.6 \\
6.6\end{array}$ & $\begin{array}{r}\times 10^{-6} \\
6.6 \\
6.6 \\
6.6 \\
6.6 \\
6.6\end{array}$ \\
\hline
\end{tabular}
and (3).

TABLE 6.-Average coefficients of expansion of tantalum

The largest variation in the coefficients of expansion given in Table 6 is $0.2 \times 10^{-6}$. The coefficients indicate that the samples of worked and annealed tantalum expand nearly the same. The rate of expansion of tantalum changes slightly with temperature.

Figure 5 shows a comparison of the average expansion curve obtained in the present investigation on tantalum, with data from previous observers. The curve was derived from equation (3) and the data at low temperatures. Most of the values of previous observers lie above the curve.

\section{SUMMARY}

This paper gives data on the linear thermal expansion of three samples of worked and annealed tantalum over various temperature ranges between $-190^{\circ}$ and $+500^{\circ} \mathrm{C}$.

Two types of expansion apparatus were used in this investigation. A summary of available data by previous observers on the thermal expansion of tantalum is included.

Worked tantalum was found to expand practically the same as annealed tantalum. The following equation is given as the most 


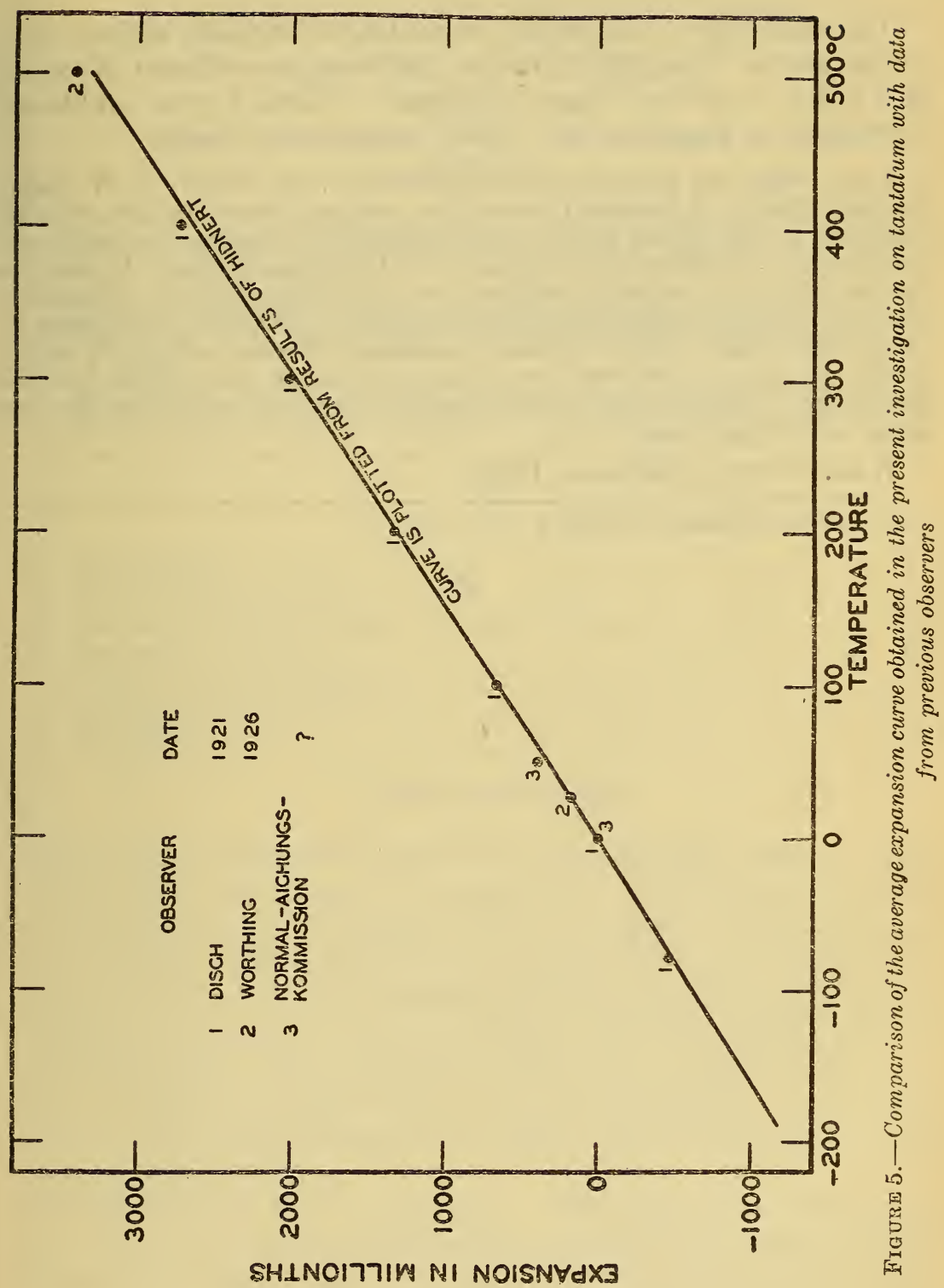


probable second-degree equation for the expansion of tantalum between $20^{\circ}$ and $500^{\circ} \mathrm{C}$.:

$$
L_{\mathrm{t}}=L_{\mathrm{o}}\left[1+\left(6.59 t+0.00008 t^{2}\right) 10^{-6}\right]
$$

The coefficient of expansion of tantalum increases slightly with temperature. From $20^{\circ}$ to $100^{\circ} \mathrm{C}$. the average coefficient of expansion is $6.6 \times 10^{-6}$ per degree centigrade. Table 6 gives additional coefficients of expansion for various temperature ranges.

Noте.-After the manuscript was submitted to the printer, C. W. Balke, chemical director, of Fansteel Products Co., informed the author that tantalum has found a very definite place ${ }^{7}$ in the manufacture of spinnerets used in the manufacture of artificial silk, particularly by the viscose process. In this connection tantalum is replacing platinum and gold-platinum alloys. Because of the very attractive interference colors which can be produced on tantalum by electrolytic oxidation, there is at present considerable interest in its use for various articles of jewelry, particularly woven mesh wrist-watch straps, beads, spectacle frames, etc. It seems quite probable that tantalum will be commercially used along some of these lines.

Washington, December, 1928.

7 For other uses of tantalum see p. 889. 